\title{
Phenolic compounds profile, neuroprotective effect and antioxidant potential of a commercial Turkish coffee
}

\author{
Perfil do componente fenólico, efeito neuroprotector \\ e potencial antioxidante de um \\ café comercial turco
}

Melek ÇOL AYVAZ1 (D) 0000-0001-5155-5784

A B S T R A C T

\section{Objective}

The purpose of this study is to determine the phenolic and flavonoid contents, and antioxidant activities and neuroprotective effects of powdered coffee sample of a commercial coffee brand originated from Sivas, Turkey.

\section{Methods}

Total phenolic, flavonoid and antioxidant contents, enzymatic and non-enzymatic antioxidative activities based on 2,2-diphenyl-1-picrylhydrazyl free radical scavenging activity, metal chelating potential, reducing power, superoxide dismutase and catalase activity tests and lipid peroxidation inhibition potentials of the ethanolic and aqueous extracts of the coffee sample were assayed using the commonly preferred spectrophotometric methods. Furthermore the extracts' cholinesterase and tyrosinase inhibition potentials were evaluated. Phenolic profiles of the coffee sample were investigated using high performance liquid chromatography.

\section{Results}

Catechin was the most frequently detected phenolic acid. In addition, it was demonstrated that the water extract has a significant impact when compared with standard antioxidants. While the $\mathrm{SC}_{50}$ (sufficient concentration to obtain $50 \%$ of a maximum scavenging capacity) value for the scavenging activity of 2,2-diphenyl-1-picrylhydrazyl free radical was calculated as being $0.08 \mathrm{mg} / \mathrm{mL}$ for water extract, the amount of chelating agents with half $\mathrm{Fe}^{2+}$ ions in the medium was found to be $0.271 \mathrm{mg} / \mathrm{mL}$. Additionally, it was shown that $0.1 \mathrm{mg} / \mathrm{mL}$ concentration of both extracts prevents lipid peroxidation by $8 \%$. Compared with standard drugs, inhibition potentials of cholinesterase and tyrosinase enzymes were considered as moderately acceptable in these samples.

1 Ordu University, Faculty of Science and Arts, Department of Chemistry. Cumhuriyet Mahallesi, Mustafa Kemal Blv, n. 478, 52200, Altinordu, Ordu, Turkey. E-mail: <melekcol@hotmail.com>.

How to cite this article

Çol Ayvaz M. Phenolic compounds profile, neuroprotective effect and antioxidant potential of a commercial Turkish coffee. Rev Nutr. 2020;33:e190097. http://dx.doi.org/10.1590/1678-9865202033e190097 


\section{Conclusion}

Besides the extracts' enzymatic antioxidant activity, their inhibition potential on cholinesterase and tyrosinase enzymes - which are important clinical enzymes - reveal that this natural source can be used as a valuable resource in different fields, especially in medicine.

Keywords: Anticholinesterase. Antioxidant effect. Free radicals. Lipid peroxidation.

\section{RE S U M O}

\section{Objetivo}

O objetivo deste estudo é determinar o conteúdo fenólico e flavonoide, bem como as atividades antioxidantes e os efeitos neuroprotetores de uma amostra de café em pó de uma promissora marca comercial proveniente de Sivas, Turquia.

\section{Métodos}

A partir dos métodos espectrofotométricos comumente utilizados, foram analisados os seguintes aspectos da amostra de café: teores de fenólicos totais, flavonoides e antioxidantes; atividades antioxidantes enzimáticas e não enzimáticas, baseadas na atividade de eliminação de radicais livres de 2,2-difenil-1-picrilhidrazila potencial quelante de metais; poder redutor; testes de atividade de superóxido dismutase e catalase; e potenciais de inibição da peroxidação lipídica dos extratos etanólicos e aquosos. Além disso, foram avaliados os potenciais de inibição da colinesterase e da tirosinase dos extratos. Os perfis fenólicos da amostra de café foram investigados por cromatografia líquida de alta eficiência.

\section{Resultados}

Entre os ácidos fenólicos estudados, o mais detectado foi a catequina. Especialmente, foi demonstrado que o extrato de água tem um impacto significativo quando comparado com os antioxidantes padrão. Determinou--se que o valor de SC $_{50}$ (a concentração suficiente para obter $50 \%$ da capacidade máxima de eliminação) da atividade de eliminação do radical 2,2-difenil-1-picrilhidrazilab/para extrato de água era de 0,08mg/mL, enquanto a quantidade de agentes quelantes com metade de Fe ${ }^{2+}$ íns na média foi encontrada como 0,271mg/ $\mathrm{mL}$. Também foi demonstrado que a concentração de $0,1 \mathrm{mg} / \mathrm{mL}$ de ambos os extratos inibe a peroxidação lipídica em cerca de $8 \%$. Comparado com drogas padrão, os potenciais de inibição das amostras nas enzimas e tirosinase foram aceitáveis como moderados.

\section{Conclusão}

Os resultados mostram que, além de terem atividade antioxidante enzimática, os extratos apresentam potencial de inibição das enzimas colinesterase e tirosinase, que são importantes enzimas clínicas, o que revela que essa fonte natural pode ser usada como um recurso valioso em vários campos, principalmente na medicina.

Palavras-chave: Anticolinesterase. Efeito antioxidante. Radicais livre. Peroxidação de lipídios.

\section{NTRODUCTION}

Since coffee is one of the most important agricultural products in international trade and has a significant commercial and social importance, coffee analysis investigations are of great importance [1]. Recent studies emphasize that regular coffee consumption (about 2-4 cups per day) is associated with a low risk of death, colorectal cancer development, liver damage, and cirrhosis, as well as degenerative, progressive and chronic diseases (Alzheimer's and Parkinson's disease, Type II diabetes, Coronary heart disease) [2]. Coffee is consumed for a variety of reasons: thanks to its caffeine content it is a stimulant drink, it is beneficial to health and has an excellent taste and aroma. Taste, aroma and caffeine content play an important role in popularity, but coffee beans contain thousands of different chemical compounds, such as carbohydrates, lipids, nitrogen compounds, vitamins, minerals, alkaloids and phenolic compounds [3]. Although other foods contain more antioxidants 
than coffee, the amount and frequency of consumption make this drink one of the main sources of dietary antioxidants [4].

Polyphenolic antioxidants have been used for centuries in preventive medicine, and human epidemiological studies support the concept that there is an inverse relationship between body antioxidant levels/consumption of coffee and the cognitive function as well as the development of neurodegenerative diseases [5]. Recently, studies have shown that progression of Alzheimer Disease $(A D)$ is slowed by the consumption of foods containing components with antioxidant activity [6]. Furthermore a study on rabbit hippocampus revealed that caffeine prevents chronic, detrimental alterations by activating the brain's antioxidant systems [7].

Neurodegenerative diseases are among the deadly diseases affecting the elderly population. In particular, it is known that Alzheimer (AD) and Parkinson (PD) diseases have a multifactorial and progressive feature and there are no complete treatment strategies for both diseases. For this reason, intensive investigations are in progress to find new drug candidates of natural or synthetic origin for the treatment of these diseases with uncertain pathogenesis. The most accepted theory for Alzheimer's disease is the cholinergic hypothesis, represented by a significant decrease in the acetylcholine level in individuals who suffer from this disease. Therefore, the inhibition of Acetylcholinesterase Enzyme (AChE) which breaks down acetylcholine in the brain is a widely used treatment strategy against AD. Similarly, the inhibition of Butyrylcholine Estrerase (BuChE), which is capable of hydrolyzing various cholinesterases, is also important for the treatment of AD. Furthermore, since Phosphodiesterases (PDEs) are broadly expressed in the brain, Phosphodiesterases inhibitors (PDEls) are considered to modulate neurodegenerative conditions through the regulation of Cyclic Adenosine Monophosphate (CAMP) and Cyclic Guanosine Monophosphate (cGMP) in the brain. The best-known PDEls are Methylxanthines (e.g. caffeine) acting as non-selective inhibitors on single isoforms of PDEs [8].

Since dementia is also associated with Parkinson's disease, cholinesterase inhibitors are also of great interest in the treatment of PD [9]. Apart from this, tyrosinase plays a role in melanin biosynthesis, which takes place in two steps. Tyrosine is converted to 3,4-Dihydroxy Phenylalanine (DOPA), a process called tyrosinase monophenolase activity. The next step is called diphenolase activity and includes oxidation of DOPA to DOPA quinone. The reactive o-quinone, DOPA quinone, polymerises spontaneously and non-enzymatically to form high molecular weight melanin. In humans, melanin is often used to protect the skin from UV radiation, but overproduction of melanin results in hyperpigmentation of the skin characterized by age spots, melasma and chloasma. Furthermore, tyrosinase is known to oxidate dopamine in order to produce melanin in the brain. Thus, tyrosinase is also associated with pathogenesis of PD and related neurodegenerative disorders [10]. Therefore, inhibition of tyrosinase has also become a popular target in drug research for Parkinson's treatment. In addition, tyrosinase inhibitors are also useful for maintaining food quality, in the development of cancer drugs as well as in the treatment of skin hyperpigmentation [11].

A number of studies have emphasized that since coffee increases neuronal stability there is an inverse relationship between Parkinson's disease and the consumption of coffee and other sources of caffein [12]. Thus, it can be said that, the beneficial effects of coffee is mainly due to the compounds it contains, caffeine being the most important ingredient. In another study, the beneficial properties of coffee were associated with methylxanthine phytochemicals, which are involved in caffeine and are abundant in coffee. Among these methylxanthines, caffeine has been extensively studied and the effects of caffeine on the functioning of the neuronal network are clearly demonstrated by supporting continuous cognitive performance. Caffeine can protect neurons against dysfunction and death in stroke, Alzheimer's disease and Parkinson's disease animal models. The mechanism of action 
of caffeine is thought to be based on antagonism of various subclasses of adenosine receptors. Apart from caffeine, metabolites such as theobromine and theophylline which are known as downstream xanthine metabolites also contribute to the beneficial properties of coffee, tea and cocoa on brain health [13]. It had been reported that levels of theobromine in the cerebral spinal fluid are inversely correlated with the amyloid beta 42 levels in Alzheimer's patients [14]. Several meta-analyses have shown that moderate coffee intake lowers one's risk of developing PD by $24-30 \%$. It should be kept in mind that the effects of coffee consumption on these neurological diseases vary according to gender, dose and hormone levels [13]. Another 21-year follow-up study dealing with 1409 subjects (875 women and 534 men), revealed that moderate consumption of coffee reduced the AD risk up to $64 \%$ in later life as compared to low coffee drinkers [15].

Drinking Turkish coffee in Turkey is an important part of both cultural and outdoor and indoor social activities. Turkish coffee is not just a type of coffee, it also has a unique preparation method: sufficient quantity of coffee and desired amount of sugar are added to preferably cold water, measured with cups. Then, the ingredients are mixed thoroughly in a narrow-topped coffee pot called cezve until the coffee gets wet and the sugar is dissolved. At the end of the mixing process, the mixture is heated. After boiling it is poured into cups and served [16].

To demonstrate the coffee benefits mentioned above, many studies on commercially available coffee brands have been performed in many countries, including Turkey. However, due to variation in coffee type, dose, range of study, selection of biomarkers and lack of information about the composition of the bioactive substances of coffee, further studies are needed to evaluate the beneficial or harmful effects of coffee on human health [4,9]. From this point of view, after investigating phenolic compounds in ethanol and water extracts of Talas brand Turkish coffee, the total phenolic and flavonoid contents were determined by spectrophotometric methods and antioxidant activities were investigated using different methods. On the other hand, the critical role of lipid peroxides in inflammation progression and regulation of inflammation has long been known due to their importance in the production of secondary precursors. Therefore, due to their role in many diseases and cause of death, intensive efforts have been made in order to identify and develop compounds that eliminate the toxic effects of lipid peroxides [17]. For this purpose, the efficacy of coffee extracts to prevent lipid peroxidation was also tested. In addition, anticholinesterase and antityrosinase activities were investigated in order to reveal the neurobiological effects of coffee extracts.Thus, in addition to similar studies found in the literature, this specific coffee brand will be evaluated by performing different analyses to find out whether the use of a different brand of Turkish coffee would be beneficial to health in various aspects.

\section{METHODS}

All chemicals used for the analyses were analytical grade and purchased from Sigma Chemical Co. (Saint Louis, USA). All high purity standards used for High Performance Liquid Chromatography (HPLC) analysis were also obtained from Sigma. Acetylcholinesterase and butyrlcholinesterase were obtained from Electrophorus electricus (electric eel) and equine serum, respectively. Tyrosinase and catalase were also obtained from mushroom and bovine liver, respectively. Spectrophotometric measurements were performed using an UV-1800 spectrophotometer.

Fifty mililiters of ethanol absolute (p.a. $\geq 99.81$ ) and/or distilled water were added to $1 \mathrm{~g}$ of ground Talas brand Turkish coffee purchased commercially in the Sivas province and extracted using 
a shaking water bath at $25^{\circ} \mathrm{C}$ for $24 \mathrm{~h}$. Subsequently, the mixture was centrifuged and extraction was performed two more times after removing the supernatant. All supernatants were mixed together and filtered using filter paper; the solvent of the ethanol extract was removed by evaporation, and the water of the water extract was removed using a lyophilizat or. After lyophilization, the ethanol and water extracts were prepared by adding ethanol and water up to a certain concentration [9].

Phenolics were analyzed using an HPLC equipment (Thermo Dionex Ultimate 3000) with a RS Diode Array detector. Analyses were carried out by using ODS Hypersil C18 column (150mmx4.6mm). Elution was carried out using $0.1 \%$ acetic acid as the solvent $A$ and acetonitrile as the solvent $B$ with a gradient program starting with $100 \%$ A, to reach $5 \%$ B after 2 min, 40\% B after 20 min and $80 \%$ $B$ after $30 \mathrm{~min}$. Optimization of the operation was performed by adjusting the injection volume of samples and standards to $10 \mu \mathrm{L}$, flow rate to $0.9 \mathrm{~mL} / \mathrm{min}$, column temperature to $25^{\circ} \mathrm{C}[18,19]$.

The phenolic compounds detected in both extracts were identified through comparison of their retention times and spectra obtained by injection of the standard solution under the same conditions. The peak area was used for quantitation, using external calibration with standards [20].

Total Phenolic Content (TPC) of the coffee sample's ethanol and water extracts was determined spectrophotometrically as Gallic Acid Equivalent (mg GAE/g sample) using Folin-Ciocalteu reagent [21]. The Total Flavonoid Content (TFC) was also determined as Quercetin Equivalent (mg QE/g sample) by using the method based on the formation of flavonoid-aluminum chloride complex [22].

The antioxidant activity of the extracts was examined using different methods. Total Antioxidant Activity (TAA) of the extracts was calculated as the Ascorbic Acid Equivalent (AAE) by the phosphomolybdenum test, based on the reduction of $\mathrm{Mo}(\mathrm{VI})$ to $\mathrm{Mo}(\mathrm{V})$ in the presence of a tested antioxidant substance and the subsequent formation of a green phosphate/Mo(V) complex in acidic medium. For this purpose the appropriate amount of the sample was combined with the reagent solution ( $0.6 \mathrm{M}$ sulfuric acid, $28 \mathrm{mM}$ sodium phosphate, and $4 \mathrm{mM}$ ammonium molybdate) in a tube. The content of the tube with a tightly closed mouth was incubated at $95^{\circ} \mathrm{C}$ for $90 \mathrm{~min}$. After the samples had cooled down to room temperature, the absorbance was measured at $695 \mathrm{~nm}$ against a blank [23].

To determine 2,2-diphenyl-1-picrylhydrazyl (DPPH) radical scavenging activities, commercially purchased stable DPPH radical was used. When DPPH interacts with an antioxidant contained in the extract, it loses hydrogen and turns into its reduced form. This change leads to a decrease in absorbance at $517 \mathrm{~nm}$ [24]. In this procedure, methanolic DPPH solution was added to the extract at different concentrations. Only the mixture containing DPPH solution and the solvent used for sample preparation was used as control. After incubation for 30min in the dark, the absorbance values were recorded and DPPH free radical scavenging activities were calculated by using the following Equation 1 .

$$
\text { Scavenging ratio }(\%)=\left[\left(\mathrm{A}_{\text {control }}-\mathrm{A}_{\text {sample }}\right) / \mathrm{A}_{\text {control }}\right] \times 100(\text { Equation 1) }
$$

The $\mathrm{SC}_{50}$ values (the extract concentration which eliminates half of the DPPH in the medium) for both extracts were calculated with the aid of a graph plotted using the scavenging ratio against concentration data.

The ability to form chelates with the iron ion was expressed by the rate of inhibition of complex formation with Ferrozine-Fe ${ }^{2+}$ and was compared with Ethylenediaminetetraacetic Acid (EDTA) [17]. The extract concentrate sufficient to reduce the concentration of Ferrozine-Fe ${ }^{2+}$ complex expected to be formed under the trial conditions was calculated by following the steps set for the in the DPPH test. 
The appropriate amount of extracts was mixed with potassium ferricyanide $(1.0 \%)$ in phosphate buffer $\left(0.1 \mathrm{M} \mathrm{pH} \mathrm{6.6)}\right.$ and incubated for 20 minutes at $50^{\circ} \mathrm{C}$ in order to demonstrate the reducing power of ethanol and water extracts. After incubation, 10.0\% trichloroacetic acid was added and after shaking, $0.1 \% \mathrm{FeCl}_{3}$ was added to the mixture. After 30 minutes, the conversion of $\mathrm{Fe}^{3+}$-ferricyanide complex to $\mathrm{Fe}^{2+}$ was recorded by reading the absorbance at $700 \mathrm{~nm}$ [25]. The greater the absorbance, the greater the reducing power.

Superoxide Dismutase (SOD) activities of the extracts were tested using the method based on the inhibition of Nitroblue Tetrazolium (NBT) reduction [26]. Extract concentrations $\left(\mathrm{IC}_{50} ; \mathrm{mg} / \mathrm{mL}\right)$ that inhibit $50 \%$ of the SOD enzyme were calculated following the same procedure used in the DPPH assay.

The extracts' catalase activities were calculated by monitoring the dismutation of hydrogen peroxide solution $\left(\mathrm{H}_{2} \mathrm{O}_{2}\right.$ ) (about $25 \mathrm{mM}$ ) spectrophotometrically at $240 \mathrm{~nm}$ after the addition of an appropriate amount of extract and/or catalase from bovine liver purchased commercially. The extinction coefficient for $\mathrm{H}_{2} \mathrm{O}_{2}$ was $42 \mathrm{M}^{-1} \mathrm{~cm}^{-1}$ [27]. $1 \mathrm{U}$ enzyme activity is defined as the amount of enzyme that catalyzes the decomposition of $1 \mu \mathrm{mol} \mathrm{H}_{2} \mathrm{O}_{2}$ per minute.

To investigate the lipid peroxidation inhibition potential, the reaction mixtures were prepared in methanol to contain $0.26 \mathrm{mM}$ linoleic acid, 2.00mM 2,2-azobis-(2-amidinopropane)-dihydrochloride (ABAP) and the appropriate amount of extracts. After 10 minutes incubation of well-mixed mixtures, changes in absorbance were measured against methanol at $234 \mathrm{~nm}$. Extract-free mixture was used as a blank [19].

The spectrophotometric method modified by Ellman et al. [28] was followed to determine the inhibition degree of water and ethanol extracts on cholinesterase enzymes of a coffee sample at $1 \mathrm{mg} / \mathrm{mL}$ concentration. Acetylcholinesterase (EC 3.1.1.7) obtained from Electrophorus electricus (electric eel) and butyrylcholinesterase (EC 3.1.1.8) from equine serum as enzyme source and acetylthiocholine iodide and butyrylthiocholine chloride as substrate were used in the reaction mixture. The drug galantamine (alkaloid type anticholinesterase) was used as reference [29]. Enzyme inhibition percentages were calculated by using the following Equation 2, comparing the reaction rate $\left(A_{\text {sample }}\right)$ of the sample against the blank $\left(A_{\text {blank }}\right)$ prepared to contain the buffer instead of the sample to be tested.

$$
\text { Inhibition percentage }(\%)=\left(\mathrm{A}_{\text {blank }}-\mathrm{A}_{\text {sample }}\right) / \mathrm{A}_{\text {blank }} \times 100 \quad \text { Equation } 2
$$

In order to examine the tyrosinase inhibition of the extracts, mushroom tyrosinase was first incubated with $0.5 \mathrm{mg} / \mathrm{mL}$ of extracts at $25^{\circ} \mathrm{C}$ for 10 minutes in $50 \mathrm{mM}$ phosphate buffer ( $\mathrm{pH}$ 6.8). Subsequently, L-DOPA was added to this mixture and the enzymatic reaction was followed by monitoring the change in absorbance at $475 \mathrm{~nm}$ due to DOPA chrome formation in 1 minute. Kojic acid was used as a standard inhibitor for comparison [23] and the tyrosinase enzyme inhibition potentials of $0.5 \mathrm{mg} / \mathrm{mL}$ portions of both standard and extracts were calculated with the aid of the equation used above. Triplicate analysis was used in all the assays and the results are expressed as mean \pm Standard Deviation (SD).

\section{RE S U L T S}

In order to determine the effect of solvents which have different polarity on the studied parameters, different biological experiments were carried out on Talas brand Turkish coffee ethanol and water extracts. 
High performance liquid chromatography analysis of extracts revealed that the coffee sample contains phenolic acids, flavonoids, hydroxycinnamic acid and stilbene type compounds (Table 1). Although the species of phenolic compounds are different, both of the extracts contain almost the same number of phenolics. While gallic acid, homogentisic acid and coumaric acid could not be detected in the ethanol extract, caffeic acid and trans-sinapic acid could not be detected in the water extract. On the other hand, catechin as a flavonoid was the most conspicuous in terms of quantity for both extracts. Pyrogallol was significantly higher in ethanol extract than in water extract.

The calculated value of total phenolic content was much higher in the case of the water extract than alcohol extract, whereas flavonoid content is the opposite (Table 2). On the other hand, in the case of the water extract, $40.50 \mathrm{mg}$ GAE of phenolic acid per $1 \mathrm{~g}$ of dry extract was obtained. This is a very valuable finding for coffee prepared with water to drink.

Table 1. Concentration $(\mathrm{mg} / \mathrm{kg}$ ) of phenolic compounds found in water and ethanol extracts of Talas branded Turkish coffee obtained from Sivas province. Ordu, Turkey, 2017

\begin{tabular}{|c|c|c|c|c|}
\hline \multirow{2}{*}{ Investigated Phenolics } & \multicolumn{2}{|c|}{ Water Extract } & \multicolumn{2}{|c|}{ Ethanol Extract } \\
\hline & Calculated value & SD & Calculated value & SD \\
\hline Pyrogallol & 1.00 & $( \pm 0.02)$ & 133.44 & $( \pm 7.59)$ \\
\hline Protocatechuic acid & 6.59 & $( \pm 0.77)$ & 2.63 & $( \pm 0.95)$ \\
\hline p-Hydroxybenzoic acid & 4.06 & $( \pm 1.03)$ & 1.36 & $( \pm 0.29)$ \\
\hline Catechin & 5098.57 & $( \pm 10.58)$ & 2614.21 & $( \pm 30.17)$ \\
\hline Vanillic acid & 0.07 & $( \pm 0.00)$ & 3.56 & $( \pm 1.25)$ \\
\hline Caffeic acid & - & - & 1.98 & $( \pm 0.58)$ \\
\hline Trans-sinapic acid & - & - & 10.03 & $( \pm 1.15)$ \\
\hline Benzoic acid & 3.52 & $( \pm 1.00)$ & 15.63 & $( \pm 3.50)$ \\
\hline Resveratrol & 1.33 & $( \pm 0.06)$ & 1.12 & $( \pm 0.30)$ \\
\hline Trans-cinnamic acid & 0.34 & $( \pm 0.01)$ & 0.27 & $( \pm 0.09)$ \\
\hline Gallic acid & 4.71 & $( \pm 1.06)$ & - & - \\
\hline Homogentisic acid & 43.64 & $( \pm 5.30)$ & - & - \\
\hline p-Coumaric acid & 1.08 & $( \pm 0.09)$ & - & - \\
\hline
\end{tabular}

Note: SD: Standard Deviation.

Table 2. Total phenolic, flavonoid and antioxidant contents, enzymatic and non-enzymatic antioxidant activities and lipid peroxidation inhibition potentials of water and ethanol extracts of Talas branded Turkish coffee obtained from Sivas province. Ordu, Turkey, 2017.

\begin{tabular}{|c|c|c|c|c|c|}
\hline \multirow[b]{2}{*}{ Assays } & \multicolumn{2}{|c|}{ Water Extract } & \multicolumn{2}{|c|}{ Ethanol Extract } & \multirow[b]{2}{*}{ Standard } \\
\hline & $\begin{array}{l}\text { Calculated } \\
\text { value }\end{array}$ & SD & $\begin{array}{l}\text { Calculated } \\
\text { value }\end{array}$ & SD & \\
\hline Total Phenolic Content (mgGAE/g dry sample) & 40.500 & $( \pm 2.560)$ & 5.560 & $( \pm 1.050)$ & - \\
\hline Total Flavonoid Content (mgQE/g dry sample) & 2.170 & $( \pm 0.010)$ & 8.740 & $( \pm 1.780)$ & - \\
\hline Total Antioxidant Activity (mgAAE/g dry sample) & 39.530 & $( \pm 3.740)$ & 20.540 & $( \pm 3.400)$ & - \\
\hline DPPH Radical Scavenging Activity $\left(\mathrm{SC}_{50} ; \mathrm{mg} / \mathrm{mL}\right)$ & 0.080 & $( \pm 0.000)$ & 0.735 & $( \pm 0.075)$ & 0.0032 for $A A$ \\
\hline Chelating Potential with $\mathrm{Fe}^{2+}\left(\mathrm{SC}_{50} ; \mathrm{mg} / \mathrm{mL}\right)$ & 0.271 & $( \pm 0.002)$ & 8.170 & $( \pm 2.560)$ & 0.03 for EDTA \\
\hline Reducing Power ( $\mathrm{Abs}_{700}$ for $0.5 \mathrm{mg} / \mathrm{mL}$ extract) & 0.618 & $( \pm 0.006)$ & 0.408 & $( \pm 0.004)$ & 0.770 for $\mathrm{AA}$ \\
\hline SOD activity $\left(\mathrm{IC}_{50} ; \mathrm{mg} / \mathrm{mL}\right)$ & 0.146 & $( \pm 0.215)$ & 1.018 & $( \pm 0.056)$ & $\begin{array}{c}10^{-27} \text { for commercial } \\
\text { SOD }\end{array}$ \\
\hline CAT activity ( $U$ for $0.05 \mathrm{mg} / \mathrm{mL}$ extract) & 0.033 & $( \pm 0.002)$ & 0.028 & $( \pm 0.001)$ & $\begin{array}{l}1.74 \text { for } 0.01 \mathrm{mg} / \mathrm{mL} \\
\text { commercial CAT }\end{array}$ \\
\hline Potential on lipid peroxidation ( $\%$; for $0.1 \mathrm{mg} / \mathrm{mL}$ extract) & 8.550 & $( \pm 1.250)$ & 8.100 & $( \pm 1.160)$ & - \\
\hline
\end{tabular}

Note: AA: Ascorbic Acid; AAE: Ascorbic Acid Equivalent; CAT: Catalase; GAE: Gallic Acid Equivalent; QE: Quercetin Equivalent; SD: Standard Deviation; SOD: Superoxide Dismutase. 
Total antioxidant activity of water extract (39.53mg AAE/g dry extract) is approximately 2 times higher than the ethanol extract (20.53mg AAE/g dry extract).

When the DPPH radical scavenging activities of water and ethanol extracts were calculated, $0.08 \mathrm{mg} / \mathrm{mL}$ concentration of water extract could scavenge $50 \%$ of the DPPH radicals in the medium, which was proportional to the TAA and TPC. However, in the case of ethanol extract, 10 times more extract $(0.735 \mathrm{mg} / \mathrm{mL})$ hardly exhibited similar activity. In this test, AA concentration, sufficient to sweep up to $50 \%$ of the radicals, was much smaller $(0.0032 \mathrm{mg} / \mathrm{mL})$ than both extracts.

On the other hand, $0.271 \mathrm{mg} / \mathrm{mL}$ concentration of the water extract had the potential to chelate half of the $\mathrm{Fe}^{2+}$ ions in the reaction medium. This value was also found to be much smaller $(0.03 \mathrm{mg} / \mathrm{mL})$ for the positive control EDTA and much larger $(8.17 \mathrm{mg} / \mathrm{mL})$ for the ethanolic extract.

A total of $0.5 \mathrm{mg} / \mathrm{mL}$ of water extract, which resulted in an absorbance of 0.618 at $700 \mathrm{~nm}$, could have higher reducing power compared to the same amount of ethanolic extract with an absorbance of 0.408 . Moreover, under the same conditions absorbance for the same concentration of AA was 0.77 .

A total of $0.146 \mathrm{mg} / \mathrm{mL}$ of the water extract is also sufficient to sweep $50 \%$ of the $\mathrm{O}_{2}{ }^{*}$ radicals present, whereas in the case of ethanol extract sweeping is about 10 times higher. When the activity test was performed under the same conditions in the presence of SOD obtained from bovine erythrocytes, the $\mathrm{IC}_{50}$ value was calculated as being $10^{-27} \mathrm{mg} / \mathrm{mL}$, which is quite small.

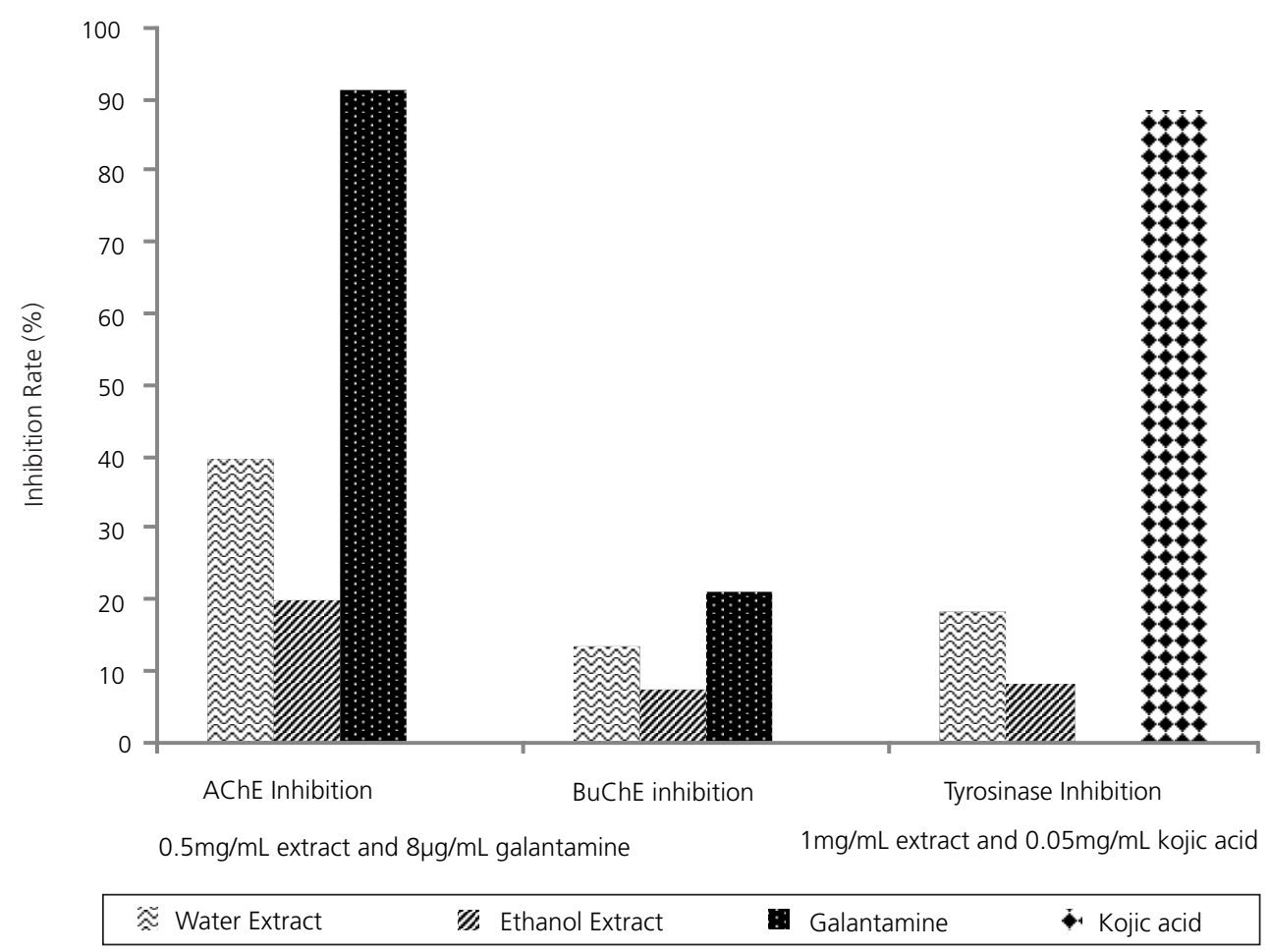

Figure 1. Anticholinesterase and antityrosinase activities of water and ethanol extracts of Talas brand Turkish coffee sample obtained from Sivas province. Ordu, Turkey, 2017.

Note: AChE: Acetylcholinesterase Enzyme; BuChE: Butrylcholinesterase Enzyme. 
Catalase activities were calculated as 0.033 for water extract and $0.028 \mathrm{U}$ for ethanol extract. The activity of the commercially purchased enzyme is, no doubt, quite high as well as the activity of the extracts $(1.74 \mathrm{U}$ for $0.01 \mathrm{mg} / \mathrm{mL}$ catalase).

The degree of inhibition of ABAP, a well-known radical initiator, inducing lipid peroxidation of coffee extracts was evaluated. Both extracts at the concentration of $0.1 \mathrm{mg} / \mathrm{mL}$ inhibited lipid peroxidation at the rate of $8 \%$.

Acetylcholinesterase enzyme and Butyrylcholine estrerase inhibitions of $1 \mathrm{mg} / \mathrm{mL}$ Talas brand ground coffee sample extracts were assessed and a moderate inhibition was observed. Although the degree of AChE inhibition is higher than BuChE, BuChE's inhibition is much more effective compared to galantamine (Figure 1).

Tyrosinase inhibition potentials at the concentration of $0.50 \mathrm{mg} / \mathrm{mL}$ in ethanol and water extracts were $8.16 \%$ and $18.42 \%$, respectively, and this value was calculated as being $88.50 \%$ for $0.05 \mathrm{mg} / \mathrm{mL}$ of kojic acid.

\section{DISCUSSION}

It cannot be deduced that the unidentified phenolics detected in the HPLC analysis are not present in the extracts. This may mean that no effective amount of these phenolics was extracted. When the literature is examined, it is seen that the phenolic component analysis of coffee samples is concentrated on caffeine $[30,31]$ and chlorogenic acid [9]. Not enough information is available on other compounds. Therefore, the present study provides important data for the literature.

The values obtained in terms of phenolic and flavonoid contents can be attributed to the fact that flavonoid-type components can be extracted in greater amounts in alcohol. When the results of the study of Köseoğlu Yılmaz et al. [32] were assessed, it was observed that the flavonoid content of the alcohol extract of the different roasted coffee samples was higher than the content in the water extract.

In a study conducted by Stelmach et al. [33] on green coffee infusions of 12 different coffe samples, total phenolic content was calculated to be $20.8-41.2 \mathrm{mg} \mathrm{GAE} / \mathrm{g}$ sample. Another study that demonstrates that our results are comparable with those obtained in studies conducted worldwide is the study of 58 different commercially available coffees (ground, soluble and caffeine-free) sold in Colombia [34].

According to those results, contribution of phenolic acids to total antioxidant activity can be considered to be much greater.

A concentration of $2 \mathrm{mg} / \mathrm{mL}$ of 18 brands of Turkish coffee marketed in Turkey was shown to have a sweeping ability between $12.55 \%$ and $56.15 \%$ [9]. According to the results of the present study, it can be understood that the antioxidant activity of Talas brand Turkish coffee is much higher than that of the 18 other coffee brands.

It is estimated that extracts or compounds which prevent metal-induced free radical development by inhibiting the formation of complexes between ferrozine and iron can prevent lipid peroxidation. Due to their phenolic contents, they might have chelating activity and turn the transition metals stable [35]. From this point of view, it is very important to examine our extracts in terms of chelating activities and the ability of water and ethanol extracts to compete with ferrozine to form chelates with $\mathrm{Fe}^{2+}$ ions in the reaction medium compared with the standard chelating agent EDTA. 
Most consumed coffee types in the western parts of Saudi Arabia [36] have been tested and it was found that the chelating potential of the tested Turkish coffee was much higher than that of the coffee types prepared with different methods

The reducing power of an extract is associated with its ability to transfer electrons and is another proof of the presence of antioxidant activity [37]. The reducing power of the water extract of the coffee sample examined is very close to the test standard ascorbic acid.

Compounds having a reducing power cause reduction of Fe3+/ferricyanide complex to $\mathrm{Fe}^{2+}$; this reduction can be monitored by measuring absorbance at $700 \mathrm{~nm}$ and the higher the absorbance the higher the reducing power. Erdem et al. [9] reported that the absorbance values at 700nm varied between 0.505 and 1.073 corresponding to the reducing power of $2 \mathrm{mg} / \mathrm{mL}$ concentration of 18 different brands of Turkish coffee. It can be concluded that these values are lower than those observed for Talas brand Turkish coffee.

So far, studies on coffee antioxidative activity both in Turkey and in the world deal with non-enzymatic antioxidant activity. So, there is not enough data on the enzymatic antioxidant activity of coffee. However, hydroxycinnamic acid, one of the main coffee phenolics, is effective in sweeping $\mathrm{O}_{2}{ }^{--}$radicals [38]. For this reason, Catalase and SOD activities were evaluated in order to reveal the enzymatic antioxidant activity of our coffee extracts. The SOD activities of extracts are quite low when compared to the commercial enzyme, but it should be remembered that we are working with raw extracts. On the other hand, the catalase activities of $0.05 \mathrm{mg} / \mathrm{mL}$ of our water and alcohol extracts are quite similar, indicating that the extraction solvent has no effect.

Biological antioxidant capacity can also be measured by controlling induced lipid peroxidation [39]. Due to their role in causing disease and death, there is a strong interest in detecting and improving compounds that controlthe toxic effects of lipid peroxides [17]. Lipid peroxidation inhibition of the extracts may be considered to occur by presenting proton to the ABAP radicals of various phenolic substances in the extract composition. Several reports showed that caffeine as a coffee component inhibited lipid peroxidation induced by reactive oxygen species [31]. Contrary to what is expected, both tested extracts have an equally small potential for inhibition of lipid peroxidation without being affected by solvent differences. Because, in case of water extract, caffeic acid could not be detected during phenolic analysis.

Enzyme inhibitors are molecules that cause pharmacological effects through inhibition of certain enzymes and constitute half of the oral drugs in clinical use [40]. Although consumption of the Turkish coffee from Coffee Arabica beans is greatly appreciated in Anatolia and neighboring countries, there are only a few studies on the neuroprotective effects of coffee extracts. Studies on the cholinesterase and tyrosinase inhibition potentials of coffee samples are rare [9]. However, it is reported that the chlorogenic acid as a characteristic coffee component and the most abundant phenolic compound has a neuroprotective effect, which is an ester of caffeic and quinic acid [41].

The ethanol and water extracts of the coffee sample had relatively greater inhibition capability on acetylcholinesterase than butyrylcholinesterase. However, the effect of both extracts on these two enzymes is very little compared to galantamine.

Arendash \& Cao [42] demonstrated the efficacy of moderate caffeine intake in the treatment of $A D$ or for protection against $A D$ in a mouse model. It is reported that potable water containing caffeine was given to mice suffering from $A D$ and was effective to protect against memory weakness and couldreduce $\beta$-amyloid levels in the brain [32]. 
When we looked at the results of the study on the effects of enzyme inhibition on 18 different brands of Turkish coffee, it was observed that most of the samples at a concentration of $200 \mu \mathrm{g} / \mathrm{mL}$ did not show AChE inhibition, but many showed BuChE inhibition at a very low concentration compared to galantamine.

Tyrosinase inhibition activity is useful in the suppression of melanogenesis which causes various dermatological disorders. It has also been reported that tyrosinase is associated with Parkinson's disease and other neurodegenerative diseases [40]. For these reasons, discovering tyrosinase inhibitors from natural sources is one of the most interesting research topics. However, there is not enough research on the antityrosinase activity of Turkish coffee, although there is information about other beneficial activities related to health.

Similar to the inhibition properties on cholinesterase, the water extract has a higher degree of tyrosinase inhibition compared to the alcohol extract. However, antityrosinase activity in both extracts is not very important besides kojic acid.

In the previous study on various coffee brands, antityrosinase activity was found in the range of $2.13 \%-15.72 \%$ for a concentration of $200 \mu \mathrm{g} / \mathrm{mL}$ [9]. The coffee extracts we have examined in this context are also candidates for use in the cosmetic and health industry.

To summarize the results of the current study, it can be said that the ethanol and water extracts of Talas brand Turkish coffee contains significant phenolic substances and that it has a good antioxidant activity, which is thought to be due to such phenolic substances.

On the other hand, the present study brings a significant contribution to the very small number of studies available in the literature concerning the inhibition potential of Turkish coffee on some clinical enzymes. Furthermore, the fact that the water extract yielded a higher result for most of the investigated parameters is an important advantage for a resource consumed as a beverage.

\section{CONCLUSION}

As a result, it can be said that thanks to its antioxidative activity Turkish coffee, which is a beverage that can be consumed frequently, can be effective both in removing toxic effects of reagents formed after normal metabolic process and in the treatment and suppression of melanogenesis with diseases such as $A D$ and PD that develop after various factors. Furthermore the consumption of coffee can contribute to the prevention and/or treatment of many diseases such as melanogenesis, $A D$, and $P D$.

\section{ACKNOWLEDGEMENT}

I would like to thank Filiz Kir and Dr. Saniye Söylemez for supplying the coffee sample and for the editing in English.

\section{REFERENCES}

1. Özdestan Ö. Evaluation of bioactive amine and mineral levels in Turkish coffee. Food Res Int. 2014;61:167-75. http://dx.doi.org/10.1016/j.foodres.2013.12.027

2. Wachamo HL. Review on health benefit and risk of coffee consumption. Med Aromat Plants. 2017;6(4):1-12. http://dx.doi.org/10.4172/2167-0412.1000301 
3. Wolska J, Janda K, Jakubczyk K, Szymkowiak M, Chlubek D, Gutowska I. Levels of antioxidant activity and fluoride content in coffee infusions of Arabica, robusta and green coffee beans in according to their brewing methods. Biol Trace Elem Res. 2017;179(2):327-33. http://dx.doi.org/10.1007/s12011-017-0963-9

4. Bedoya-Ramírez D, Cilla A, Contreras-Calderón J, Alegría-Torán A. Evaluation of the antioxidant capacity, furan compounds and cytoprotective/cytotoxic effects upon Caco-2 cells of commercial Colombian coffee. Food Chem. 2017;219:364-72. http://dx.doi.org/10.1016/j.foodchem.2016.09.159

5. Losada-Barreiro S, Bravo-Díaz C. Free radicals and polyphenols: the redox chemistry of neurodegenerative diseases. Eur J Med Chem. 2017;133:379-402. http://dx.doi.org/10.1016/j.ejmech.2017.03.061

6. Solfrizzi V, Panza F, Capurso A. The role of diet in cognitive decline. J Neural Transm. 2003;110(1):95-110. http://dx.doi.org/10.1007/s00702-002-0766-8

7. Prasanthi JRP, Dasari B, Marwarha G, Larson T, Chen X, Geiger JD, et al. Caffeine protects against oxidative stress and Alzheimer's disease-like pathology in rabbit hippocampus induced by cholesterol-enriched diet. Free Radic Biol Med. 2010;49(7):1212-20. http://dx.doi: 10.1016/j.freeradbiomed.2010.07.007

8. Nabavi SM, Talarek S, Listos J, Nabavi SF, Devi KP, Oliveira MR, et al. Phosphodiesterase inhibitors say NO to Alzheimer's disease. Food Chem Toxicol. 2019;134:110822. http://dx.doi.org/10.1016/j.fct.2019.110822

9. Erdem SA, Senol FS, Budakoglu E, Orhan IE, Sener B. Exploring in vitro neurobiological effects and highpressure liquid chromatography-assisted quantitation of chlorogenic acid in 18 Turkish coffee brands. J Food Drug Anal. 2016;24(1):112-20. http://dx.doi.org/10.1016/j.jfda.2015.08.001

10. Tan $X$, Song YH, Park C, Lee KW, Kim JY, Kim DW, et al. Highly potent tyrosinase inhibitor, neorauflavane from Campylotropis hirtella and inhibitory mechanism with molecular docking. Bioorg Med Chem. 2016;24(2):153-9. http://dx.doi.org/10.1016/j.bmc.2015.11.040

11. Chen MJ, Hung CC, Chen YR, Lai ST, Chan CF. Novel synthetic kojic acid-methimazole derivatives inhibit mushroom tyrosinase and melanogenesis. J Biosci Bioeng. 2016;122(6):666-72. http://dx.doi.org/10.1016/j. jbiosc.2016.06.002

12. Ahsan F, Bashir S. Coffee consumption: health perspectives and drawbacks. J Nutr Obes. 2019;2(1):1-4.

13. Camandola S, Plick N, Mattson MP. Impact of coffee and cacao purine metabolites on neuroplasticity and neurodegenerative disease. Neurochem Res. 2019;44(1):214-27. http://dx.doi: 10.1007/s11064-018-2492-0

14. Travassos M, Santana J, Baldeiras I, Tsolaki M, Gkatzima O, Sermin G, et al. Does caffeine consumption modify cerebrospinal fluid amyloid-b levels in patients with Alzheimer's disease? J Alzheimers Dis. 2015;47(4):1069-78. http://dx.doi.org/10.3233/JAD-150374

15. Eskelinen $M H$, Ngandu T, Tuomilehto J, Soininen $H$, Kivipelto $M$. Midlife coffee and tea drinking and the risk of late-life dementia: a population-based CAIDE study. J Alzheimers Dis. 2009;16(1):85-91. http:// dx.doi:10.3233/JAD-2009-0920

16. Kuçukomurler S, Ozgen L. Coffee and Turkish coffee culture. Pak J Nutr. 2009;8(10):1693-700. http://dx.doi. org./103923/pjn.2009.1693.1700

17. Gaschler MM, Stockwell BR. Lipid peroxidation in cell death. Biochem Biophys Res Commun. 2017;482(3):41925. http://dx.doi.org/10.1016/j.bbrc.2016.10.086

18. Öztürk M, Tel G, Aydoğmuş Öztürk F, Duru ME. The cooking effect on two edible mushrooms in anatolia: fatty acid composition, total bioactive compounds, antioxidant and anticholinesterase activities. Rec Nat Prod. 2014;8(2):189-94.

19. Çol Ayvaz M. Phenolic profile and cholinesterase, tyrosinase, urease and lipid peroxidation inhibition potentials of artemisia argyi from Ordu, Turkey. Celal Bayar Uni J Sci. 2019;15(1):29-33. http://dx.doi. org/10.18466/cbayarfbe.430835

20. Kouassi KA, Kouadio EJP, Konan KH, Dué AD, Kouamé LP. Phenolic compounds, organic acid and antioxidant activity of Lactarius subsericatus, Cantharellus platyphyllus and Amanita rubescens, three edible ectomycorrhizal mushrooms from center of Côte d'Ivoire. Eurasian J Anal Chem. 2016;11(3):127-39. http:// dx.doi.org/10.12973/ejac.2016.127a

21. Singleton VL, Rossi JA. Colorimetry of total phenolics with phosphomolibdic-phosphotungtic acid reagents. Am J Enol Vitic. 1965;16(3):144-58.

22. Silva LAL, Pezzini BR, Soares L. Spectrophotometric determination of the total flavonoid content in Ocimum basilicum L. (Lamiaceae) leaves. Pharmacogn Mag. 2015;11(41):96-101. http://dx.doi.org/10.4103/0973-1 296.149721

23. Kasangana PB, Haddad PS, Stevanovic T. Study of polyphenol content and antioxidant capa city of Myrianthus arboreus (Cecropiaceae) root bark extracts. Antioxidants. 2015;4(2):410-26. http://dx.doi.org/10.3390/ antiox4020410 
24. Priftis A, Stagos D, Konstantınopoulos K, Tsıtsımpıkou C, Spandıdos DA, Tsatsakıs AM, et al. Comparison of antioxidant activity between green and roasted coffee beans using molecular methods. Mol Med Rep. 2015;12(5):7293-302. http://dx.doi.org/10.3892/mmr.2015.4377

25. Prıftıs A, Papıkınos K, Koukoulanakı M, Kerasıotı E, Stagos D, Konstantınopoulos K, et al. Development of an assay to assess genotoxicity by particulate matter extract. Mol Med Rep. 2017;15(4):1-9. http://dx.doi. org/10.3892/mmr.2017.6171

26. Beauchamp C, Fridovich I. Superoxide dismutase: improved assays and an assay applicable to acrylamide gels. Anal Biochem. 1971;44(1):276-87. http://dx.doi.org/10.1016/0003-2697(71)90370-8

27. Keyhani J, Keyhani E. Anti-oxidative stress enyzmes in golden chanterelle (Cantharellus cibarius). In: Mendez-Vilas A, editor. Microbes in applied research. Singapore: World Scientific; 2012. p.23-7.

28. Ellman GL, Courtney KD, Andres V, Featherstone RM. A new and rapid colorimetric determination of acetylcholinesterase activity. Biochem Pharmacol. 1961;7(2):88-95. http://dx.doi.org/10.1016/0006-29 52(61)90145-9

29. Bozkurt B, Coban G, Kaya Gl, Onur MA, Unver-Somer N. Alkaloid profiling, anticholinesterase activity and molecular modeling study of Galanthus elwesii. S Afr J Bot. 2017;113:119-27. http://dx.doi.org/10.1016/j. sajb.2017.08.004

30. Fajara BEP, Susanti H. HPLC determination of caffeine in coffee beverage. Proceedings of International Pharmacy Conference UAD on product authentication: key factor in quality control of pharmaceutical products; 2017 Sept 9; Yogyakarta, Indonesia. Bristol: IOP Publishing; 2017;259:012011. http://dx.doi. org/10.1088/1757-899X/259/1/012011.

31. Motora KG, Beyene TT. Determınation Of Caffeine In Raw and Roasted Coffee Beans Of Ilu Abba Bora Zone, South West Ethiopia. Indo Am J Pharm Res. 2017; 7(9):463-70. http://dx.doi.org/10.5281/zenodo.1036324

32. Köseoğlu Yılmaz P, Hacıbekıroğlu I, Kolak U. Effect of roasting on antioxidant and anticholinesterase capacities of coffee. J Food Nutr Res. 2014;53(3):232-9.

33. Stelmach E, Pohl P, Szymczycha-Madeja A. The content of Ca, Cu, Fe, Mg and Mn and antioxidant activity of green coffee brews. Food Chem. 2015;182:302-8. http://dx.doi.org/10.1016/j.foodchem.2015.02.105

34. Contreras-Calderón J, Mejía-Díaz D, Martínez-Castaño M, Bedoya-Ramírez D, López-Rojas N, Gómez-Narváez $\mathrm{F}$, et al. Evaluation of antioxidant capacity in coffees marketed in Colombia: relationship with the extent of non-enzymatic browning. Food Chem. 2016;209:162-70. http://dx.doi.org/10.1016/j.foodchem.2016.04.038

35. Çol Ayvaz M. Antioxidant activity of Trachystemon orientalis (L.) G. Don (Borage) grown and eaten as food in Ordu, Turkey. Herba Pol. 2015;61(4):40-51. http://dx.doi.org/10.1515/hepo-2015-0030

36. Al Doghaither HA, Almowalad AM, Shorbaji AM, Al-Ghafari AB, Omar UM. Assessment of the antioxidant properties of the most common coffee brews available in the local markets of the Western region of Saudi Arabia. J Exp Biol Agric Sci. 2017;5(1):70-6. http://dx.doi.org/10.18006/2017.5(1).070.076

37. Fu R, Zhang Y, Guo Y, Liu F Chen F. Determination of phenolic contents and antioxidant activities of extracts of Jatropha curcas L. seed shell, a by-product, a new source of natural antioxidant. Ind Crop Prod. 2014;58:265-70. http://dx.doi.org/10.1016/j.indcrop.2014.04.031

38. Iwai K, Kishimoto N, Kakino Y, Mochida K, Fujita T. In vitro antioxidative effects and tyrosine inhibitory activities of seven hydroxycinnamoyl derivatives in green coffee beans. J Agric Food Chem. 2004;52(15):4893-8. http://dx.doi.org/10.1021/jf040048m

39. Watanabe T, Nakajima $Y$, Konishi T. In vitro and in vivo anti-oxidant activity of hot water extract of Basidiomycetes- $X$, newly identified edible fungus. Biol Pharm Bull. 2008;31(1):111-7.http://dx.doi. org/10.1248/bpb.31.111

40. Rengasamy KRR, Kulkarni MG, Stirk WA, Van Staden J. Advances in algal drug research with emphasis on enzyme inhibitors. Biotechnol Adv. 2014;32(8):1364-81. http://dx.doi.org/10.1016/j.biotechadv.2014.08.005

41. Oliveira-Neto JR, Rezende SG, Reis CF, Benjamin SR, Rocha ML, Gil ES. Electrochemical behavior and determination of major phenolic antioxidants in selected coffee samples. Food Chem. 2016;190:506-12. http://dx.doi.org/10.1016/j.foodchem.2015.05.104

42. Arendash GW, Cao C. Caffeine and coffee as therapeutics against Alzheimer's disease. J Alzheimers Dis. 2010;20(S1):117-26. http://dx.doi.org/10.3233/JAD-2010-091249

Receveid: June 17, 2019

Final version: December 18, 2019

Approved: February 17, 2020 